\title{
Carbon Dynamics in Humic Fractions of Soil Organic Matter Under Different Vegetation Cover in Southern Tocantins
}

\author{
Josué Luiz Marinho Junior ${ }^{1}$ \\ Victor Casimiro Piscoya ${ }^{2}$ \\ Milton Marques Fernandes ${ }^{3}$ \\ Saulo Boldrini Gonçalves ${ }^{1}$ \\ Francisco Sandro Rodrigues Holanda ${ }^{4}$ \\ Moacyr Cunha Filho ${ }^{2}$ \\ Raimundo Rodrigues Gomes Filho ${ }^{4}$ \\ Alceu Pedrotti ${ }^{4}$ \\ Renisson Neponuceno Araújo Filho ${ }^{1}$
}

\begin{abstract}
Soil organic matter has great importance in chemical, physical and biological processes in soil-plant system. This study aimed to evaluate changes in carbon humic fractions of soil organic matter under different vegetation coverings in Cerrado in Tocantins, Brazil. The work was developed in Eucalyptus sp., Pasture, Agriculture and Cerrado sensu stricto areas. Soil samples were collected in dry period, October, 2018, in trenches $70 \times 70 \mathrm{~cm}$ at depths $0-10,10-20$, 20-30, 30-40 and 40-50 cm, with six replications. The vegetation cover in Eucalyptus sp. area showed higher levels of total carbon in soil humic fraction. Respectively fulvic acid, humic acid and humin in Eucalyptus sp. area had stocks of $22.09 ; 2.71$ and $20.01 \%$ higher than native forest, 32.04; 2.57 and 35.59\% higher than pasture and 10.59; 19.19 and $7.61 \%$ higher than the agriculture area. Among the different areas evaluated, the soil of Eucalyptus sp. has great potential to increase carbon storage in soil humic fractions.
\end{abstract}

Keywords: Humic acid, Fulvic acid, Humin, Cerrado.

\section{INTRODUCTION AND OBJECTIVES}

Soil organic matter (SOM) is extremely important as soil quality key indicator, as its accumulation influences physical and chemical properties of soil (Dhaliwal et al., 2019). Humus is result of biological animals decomposition, microorganisms and mainly plants, consisting of compounds in various stages of decomposition, closely linked to soil clay minerals (Stevenson, 1994).

The SOM is a nutrientes reserve for plants, with carbon (C) a large part of its composition (Ondrasek et al., 2019), it helps in physical structure of the soil such as porosity and stability of aggregates, facilitating development roots, fungi and water infiltration (Souza et al., 2019).

The SOM has two fundamental groups, one consisting in decomposition products of organic residues and microorganisms metabolism that represents about 10 to $15 \%$ of the TOC reserve in mineral soils (Dhaliwal et al., 2019) and humic substances, with emphasis on humic acid, fulvic acid and humin, representing 85 to $90 \%$ of TOC reserve (Pegoraro et al., 2018). The humic fraction is composed of organic residues having a high decomposition degree,

${ }^{1}$ Universidade Federal do Tocantins, Gurupi, TO, Brasil

${ }^{2}$ Universidade Federal Rural de Pernambuco, Recife, PE, Brasil

${ }^{3}$ Universidade Federal de Sergipe, Departamento de Ciências Florestais, Aracaju, SE, Brasil

${ }^{4}$ Universidade Federal de Sergipe, São Cristóvão, SE, Brasil 
which generates greater molecular stability indicating a longer soil $\mathrm{C}$ permanence, with this fraction retaining most of soil C (Petter et al., 2017).

The $\mathrm{C}$ in fulvic acid has great solubility in acid and basic environments, being easily leached and distributed more evenly between soil layers and presenting lower concentrations between humic soil fractions (Kukuls et al., 2019). The C in humin fraction is associated with mineral soil fraction showing strong resistance to microbial activity (Stevenson, 1994). Carbon in humic acid and humin is more recalcitrant with greater stability and presence in unchanged soils (Gmach et al., 2018; Kunlanit et al., 2019).

Thus, changes in vegetation covers use, depending on the management applied, can reduce or increase the $\mathrm{C}$ stocks in humic fractions (Santana et al., 2019). One way to mitigate C emission in atmosphere is preservation of native forests and reforestation, measures like these remove large amounts of $\mathrm{CO}_{2}$ from the atmosphere, through photosynthesis, and store $\mathrm{C}$ in biomass and soil (Soleimani et al., 2019).
Undisturbed ecosystems, such as virgin native forests and areas reforested with eucalyptus, are highly conservative environments of SOM (Primieri et al., 2017). The physicalbiochemical protection generated by the humic fractions through the recalcitrant $\mathrm{C}$ in aggregates is one of main preservation mechanisms of soils $C$ in different vegetation coverings (Zhang et al., 2019).

In light above discussion, the objective this study was to evaluate possible changes in humic fractions carbon of soil organic matter under different vegetation coverings in Cerrado in Tocantins, Brazil.

\section{MATERIALS AND METHODS}

\subsection{Study area}

The work was carried out in municipality Gurupi, state of Tocantins, in geographical coordinates $11^{\circ} 46^{\prime} 25^{\prime \prime} \mathrm{S}$ and 4902'54” W (Figure 1).
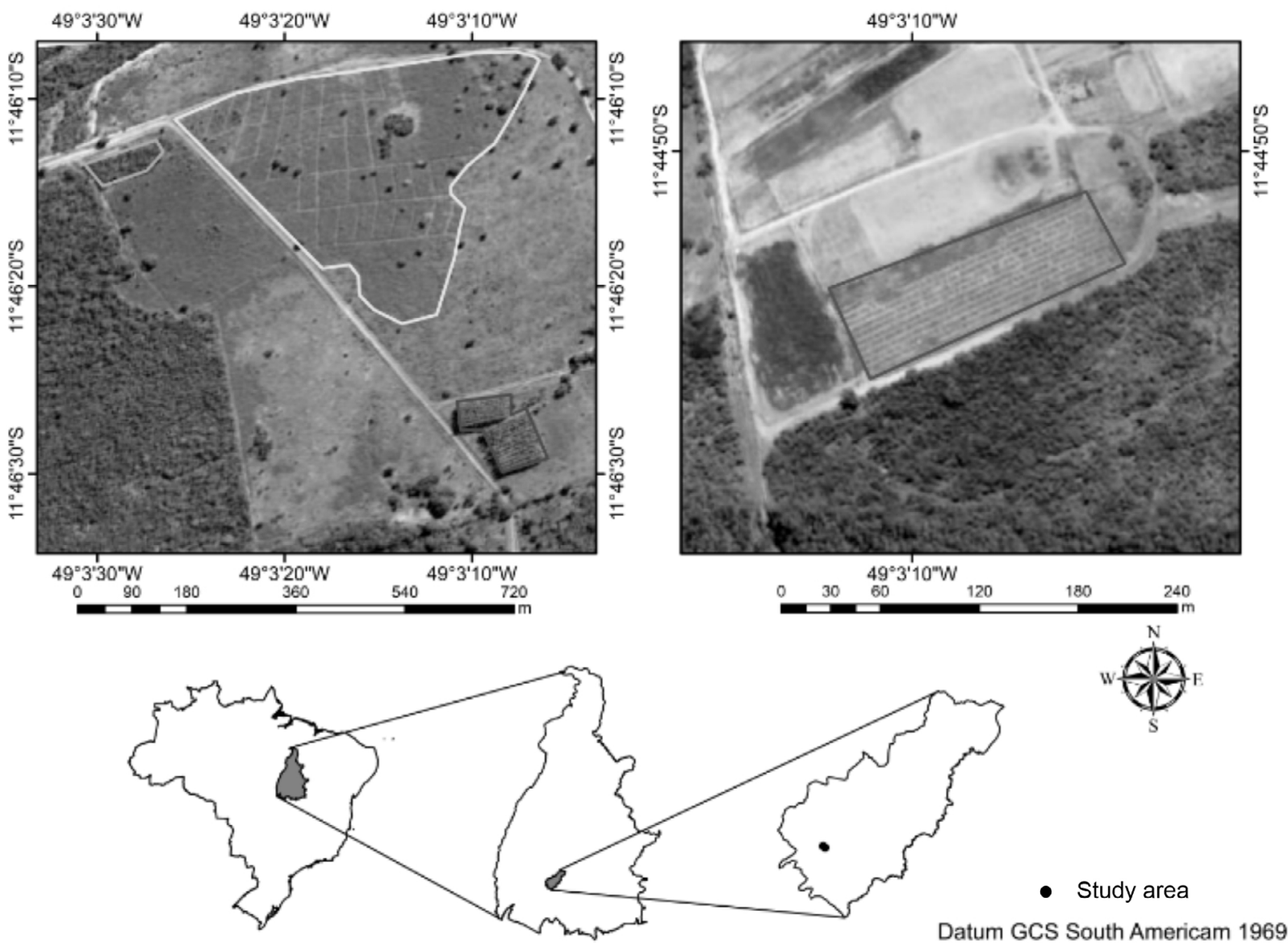

Figure 1. Experimental areas location with native forest, Eucalyptus sp., pasture and agriculture in Gurupi-TO. 
Climate of region according Thornthwaite is B1wA'a' type, having two well-defined seasons, with about six months of drought including the winter period and six months of rain that correspond to the summer. The average annual temperature is $27^{\circ} \mathrm{C}$ and the average annual precipitation is $1,500 \mathrm{~mm}$ (SEPLAN, 2017). The soil was classified as Plinthosol (Santos et al., 2018). The studied areas were with native forest of Cerrado sensu stricto as a witness, Eucalyptus sp., pasture and agriculture. Each area had the following characteristics:

Native forest of Cerrado sensu stricto: the area has 22.82 ha, aged over 60 years and has a mean diameter breast height $(\mathrm{DBH})$ of $23.1 \mathrm{~cm}$. The vegetation was characterized by five species of higher values of importance Myrcia splendens (Sw.) DC. (13.04\%), Qualea multiflora Mart. (9.87\%), Protium heptaphyllum (Aubl.) Marchand (7.53\%), Magonia pubescens A.St.-Hil. (5.35\%), Qualea grandiflora Mart. (5.02\%) (Bendito et al., 2018).

Eucalyptus sp.: the area has 0.65 ha at 11 years of age, presenting an average $\mathrm{DBH}$ of $32.7 \mathrm{~cm}$ and its implementation was carried out through deforestation with a crawler tractor and front blade, then plowing and harrowing was carried out. Seedlings with a height of $25 \mathrm{~cm}$ were planted in pits in the dimensions of $0.4 \times 0.4 \times 0.4 \mathrm{~m}$ with the help of diggers, and with a $3 \times 2 \mathrm{~m}$ spacing. Then, fertilization was carried out with $100 \mathrm{~g}$ of simple superphosphate at the bottom of the pit and partially buried, then $150 \mathrm{~g}$ of $\mathrm{pit}^{-1}$ NPK was added in formulation 5-25-15.

Pasture: the area has 11.25 ha with natural pasture and predominance of Andropogon grass over 40 years old. Other species of poaceas have been recorded such as: Spalum notatum, Eragrostis bahiensis, Axonopus affinis, Bothriochloa laguroides, Schizachyrium microstachyum, Paspalum dilatatum, Sporobolus indicus, Rhynchospora sp., Andropogon ternatus, Panpalumis sp. (Marinho et al., 2017).

Agriculture: the area has $0.95 \mathrm{ha}$ and the soil preparation was done using a leveling harrow and disc plow, and the weeds were controlled by manual weeding associated with the use of full-action herbicides such as glyphosate, operations adopted when necessary. Over the past 6 years the corn crop was grown in the area (Vaz-de-Melo et al., 2017), planted annually in the period between February and March at an average spacing of $0.2 \times 0.8 \mathrm{~m}$ (Simon et al., 2016). For sowing, a manual planter-fertilizer was used, which enabled basic fertilization. The nutrients applied at the time of corn sowing consisted of nitrogen in the form of ammonium sulphate $(45 \% \mathrm{~N})$, phosphorus in the form of triple superphosphate $\left(42 \% \mathrm{P}_{2} \mathrm{O}_{5}\right)$ and potassium in the form of potassium chloride $\left(58 \%\right.$ of $\left.\mathrm{K}_{2} \mathrm{O}\right)$, corresponding to 120,170 and $140 \mathrm{~kg} \mathrm{ha}^{-1}$, respectively of $\mathrm{N}, \mathrm{P}$ and $\mathrm{K}$, with $\mathrm{N}$ applied $50 \%$ at 25 days and $50 \%$ at 45 days after sowing (Vaz-de-Melo et al. , 2017).

The study areas characterization was carried out based on studies carried out in same areas.

\subsection{Soil samples}

Six trenches were opened per area, the first being selected at random and the rest equidistant from each other around $30 \mathrm{~m}$, with dimensions $70 \times 70 \mathrm{~cm}$ and depth of $50 \mathrm{~cm}$ in each area. The samples were collected in dry period in October, 2018, at depths 0-10, 10-20, $20-30,30-40$ and $40-50 \mathrm{~cm}$. The deformed soil samples were air dried at room temperature and passed through a $2 \mathrm{~mm}$ sieve to perform physical and chemical analyzes. Undeformed soil samples were collected and submitted to soil density analysis.

\subsection{Physical analysis}

The soil density was determined by volumetric cylinder method described by Almeida et al. (2017), and granulometric analysis was performed using the pipette method (Donagemma et al., 2017).

\subsection{Chemical analysis}

The chemical fractionation of humic substances was carried out according to the method suggested by the International Humic Substances Society (Swift, 1996). Fulvic acids (FA), humic acids (HA) and humin (HUM) were obtained, based on the solubility in acids and alkalis. After fractionation, the samples were frozen and lyophilized to determine $\mathrm{C}$ in humic fractions by the dry combustion method (CHNS / O) in an elemental analyzer (Model PE2400 Series II Perkin Elmer).

The $\mathrm{C}$ concentrations were converted into soil carbon stock in $\mathrm{Mg} \mathrm{ha}^{-1}$ for each depth sampled as follows (Veldkamp, 1994):

Stock $C=\left(C \times S_{D} \times V S D\right) \times 1000$

Where Stock $\mathrm{C}$ is the carbon stock in the soil layer, in $\left(\mathrm{Mg} \mathrm{ha}^{-1}\right) ; \mathrm{C}$ is the carbon concentration in the soil sample, in $\left(\mathrm{kg} \mathrm{Mg}^{-1}\right) ; \mathrm{S}_{\mathrm{D}}$ is the soil density in the layer, in $\left(\mathrm{Mg} \mathrm{m}^{-3}\right)$ and the VSD is the volume of the sampled depth, in $\left(\mathrm{m}^{3}\right)$. After calculating the $\mathrm{C}$ stock for each layer, the soil carbono stocks was corrected, taking into account the 
differences in soil mass (Sisti et al., 2004). The total stock of $C$ at a depth of 0 to $50 \mathrm{~cm}$ was calculated by adding the values obtained in each sampled layer.

\subsection{Statistical analysis}

The parameters evaluated, concentrations and stocks of $\mathrm{C}$ in the humic fractions were subjected to normality tests Shapiro and Wilk, then performed the analysis of variance to evaluate the differences between the soil uses in depths. The comparison of means was performed by the Tukey test at $5 \%$ significance and using the statistical software SISVAR (Ferreira, 2011).

\section{RESULTS AND DISCUSSION}

In general, the granulometric composition of soil showed a médium texture predominance, being thus classified with a sandy-clay-loam texture in all soil depths of the analyzed areas (Table 1).

Table 1. Physical characteristics of the Cerrado soil in the different vegetation coverings in Gurupi-TO.

\begin{tabular}{|c|c|c|c|c|c|c|}
\hline \multirow{2}{*}{ Vegetal Cover } & Coarse Sand & Fine Sand & Silt & Clay & Soil Density & \multirow{2}{*}{ Texture } \\
\hline & \multicolumn{4}{|c|}{ 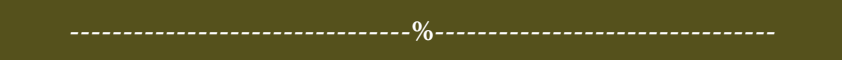 } & \multirow[t]{2}{*}{$\mathrm{g} \mathrm{cm}^{-3}$} & \\
\hline \multicolumn{6}{|c|}{ Depth 0-10 cm } & \\
\hline Native Forest & $57.50 \pm 2.85$ & $6.33 \pm 1.89$ & $8.44 \pm 1.32$ & $27.73 \pm 3.01$ & $1.45 \pm 0.06$ & Sandy-clay-loam \\
\hline Eucalyptus sp. & $54.85 \pm 3.12$ & $9.98 \pm 2.99$ & $9.19 \pm 1.23$ & $25.98 \pm 2.38$ & $1.40 \pm 0.05$ & Sandy-clay-loam \\
\hline Pasture & $55.59 \pm 1.79$ & $13.44 \pm 1.63$ & $6.64 \pm 0.57$ & $24.33 \pm 1.21$ & $1.55 \pm 0.08$ & Sandy-clay-loam \\
\hline Agriculture & $56.71 \pm 1.59$ & $9.41 \pm 3.71$ & $7.86 \pm 0.80$ & $26.02 \pm 3.32$ & $1.37 \pm 0.06$ & Sandy-clay-loam \\
\hline \multicolumn{7}{|c|}{ Depth $10-20 \mathrm{~cm}$} \\
\hline Native Forest & $59.96 \pm 2.03$ & $4.71 \pm 2.12$ & $8.51 \pm 2.33$ & $26.82 \pm 2.24$ & $1.51 \pm 0.05$ & Sandy-clay-loam \\
\hline Eucalyptus sp. & $56.04 \pm 2.24$ & $9.09 \pm 1.90$ & $6.85 \pm 2.17$ & $28.02 \pm 1.91$ & $1.53 \pm 0.07$ & Sandy-clay-loam \\
\hline Pasture & $57.84 \pm 1.32$ & $10.55 \pm 1.84$ & $7.26 \pm 1.75$ & $24.35 \pm 1.76$ & $1.59 \pm 0.05$ & Sandy-clay-loam \\
\hline Agriculture & $57.84 \pm 1.86$ & $8.92 \pm 2.09$ & $7.54 \pm 1.19$ & $25.70 \pm 2.90$ & $1.49 \pm 0.08$ & Sandy-clay-loam \\
\hline \multicolumn{7}{|c|}{ Depth $20-30 \mathrm{~cm}$} \\
\hline Native Forest & $59.30 \pm 2.36$ & $4.67 \pm 3.09$ & $8.47 \pm 1.44$ & $27.56 \pm 2.66$ & $1.55 \pm 0.03$ & Sandy-clay-loam \\
\hline Eucalyptus sp. & $55.62 \pm 1.56$ & $7.53 \pm 1.81$ & $8.38 \pm 1.48$ & $28.47 \pm 1.08$ & $1.57 \pm 0.05$ & Sandy-clay-loam \\
\hline Pasture & $58.31 \pm 1.02$ & $8.98 \pm 1.39$ & $7.10 \pm 0.80$ & $25.61 \pm 1.36$ & $1.62 \pm 0.07$ & Sandy-clay-loam \\
\hline Agriculture & $57.67 \pm 2.23$ & $8.28 \pm 3.47$ & $6.56 \pm 0.73$ & $27.49 \pm 2.70$ & $1.51 \pm 0.07$ & Sandy-clay-loam \\
\hline \multicolumn{7}{|c|}{ Depth $30-40 \mathrm{~cm}$} \\
\hline Native Forest & $58.43 \pm 3.23$ & $4.43 \pm 2.89$ & $8.68 \pm 1.55$ & $28.46 \pm 2.33$ & $1.62 \pm 0.03$ & Sandy-clay-loam \\
\hline Eucalyptus sp. & $55.89 \pm 1.68$ & $8.75 \pm 2.08$ & $8.82 \pm 1.68$ & $26.54 \pm 2.36$ & $1.65 \pm 0.04$ & Sandy-clay-loam \\
\hline Pasture & $58.16 \pm 1.44$ & $9.44 \pm 2.17$ & $6.23 \pm 1.46$ & $26.17 \pm 1.81$ & $1.64 \pm 0.06$ & Sandy-clay-loam \\
\hline Agriculture & $57.39 \pm 2.22$ & $7.44 \pm 3.78$ & $6.74 \pm 1.00$ & $28.43 \pm 4.05$ & $1.57 \pm 0.03$ & Sandy-clay-loam \\
\hline \multicolumn{7}{|c|}{ Depth $40-50 \mathrm{~cm}$} \\
\hline Native Forest & $58.46 \pm 3.16$ & $5.52 \pm 4.19$ & $8.38 \pm 1.78$ & $27.64 \pm 2.00$ & $1.65 \pm 0.03$ & Sandy-clay-loam \\
\hline Eucalyptus sp. & $55.95 \pm 1.62$ & $7.93 \pm 1.62$ & $8.85 \pm 1.47$ & $27.27 \pm 2.98$ & $1.68 \pm 0.02$ & Sandy-clay-loam \\
\hline Pasture & $57.57 \pm 1.54$ & $8.78 \pm 2.75$ & $6.85 \pm 1.13$ & $26.80 \pm 2.65$ & $1.69 \pm 0.04$ & Sandy-clay-loam \\
\hline Agriculture & $57.04 \pm 2.45$ & $6.89 \pm 2.55$ & $7.23 \pm 0.45$ & $28.84 \pm 3.64$ & $1.61 \pm 0.07$ & Sandy-clay-loam \\
\hline
\end{tabular}


The predominance of sand indicates that soil has a low capacity for nutrient retention (Araújo Filho et al., 2017). In general, the soil density did not show great variation between the types of land use (Araújo Filho et al., 2018). For Marinho Junior et al. (2019) the removal of vegetation cover can cause physical changes in soil, due to the impact of raindrops that fall directly on the exposed soil, this can explain the high soil density in superficial layers, as well as, the density increase with the depth increase of soil is attributed to densification caused by the upper layers.

The carbon concentrations in soil humic fractions: fulvic acid (FA), humic acid (HA) and humin (HUM) were represented in Figure 2.
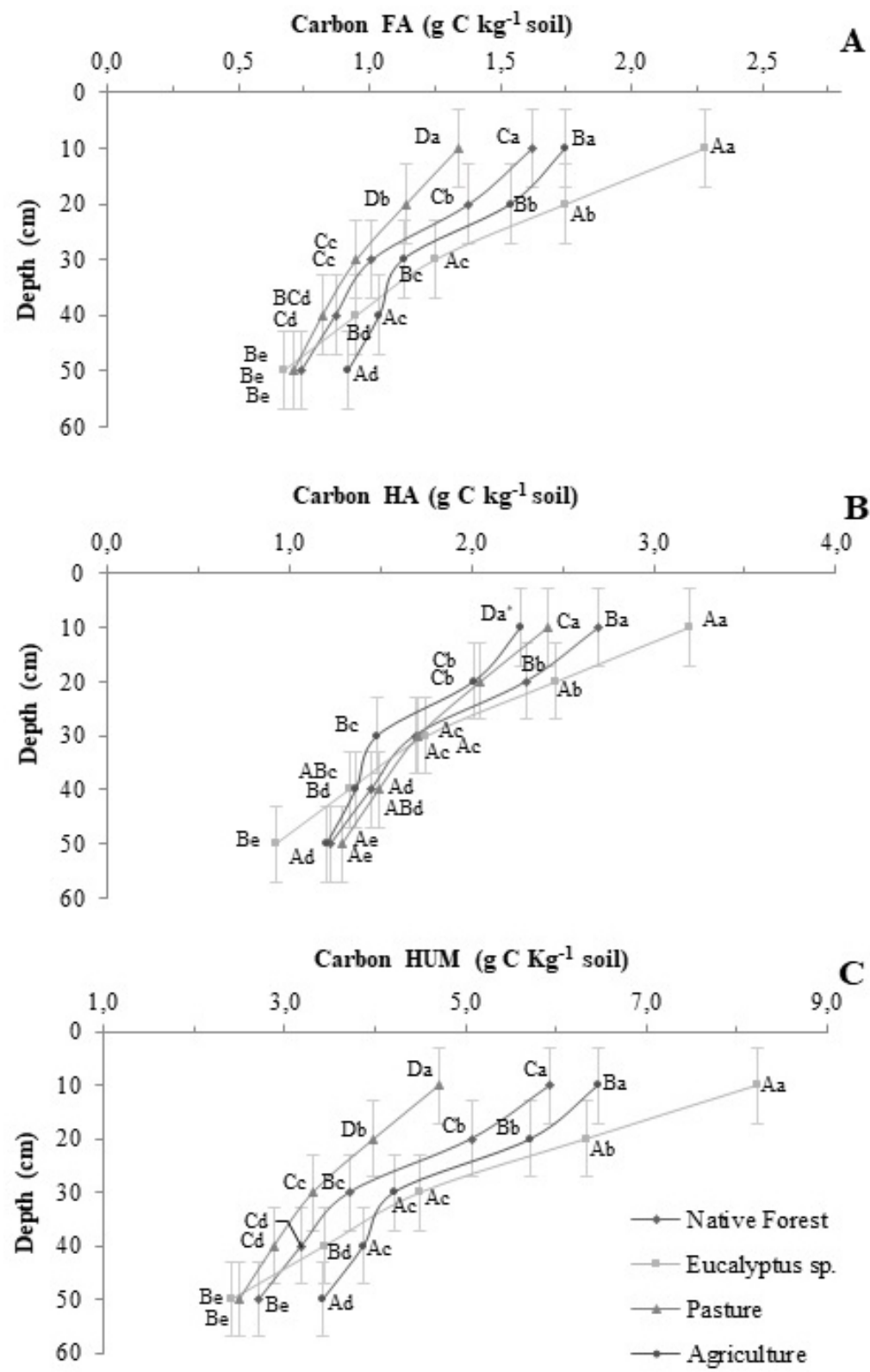

Figure 2. Carbon concentrations in humic fractions in different vegetation coverings in Gurupi-TO.

HA: Humic Acid; FA: Fulvic Acid; HUM: Humin.

"Significant differences are indicated by different letters by the Tukey test at $5 \%$ significance level $(\mathrm{P} \leq 0.05)$. Capital letters indicate differences between vegetation cover and lower letters indicate differences between soil layers. 
The carbon concentrations in soil humic fractions decreased with depth increase, finding the maximum values in the layer of $0-10 \mathrm{~cm}$ and minimum values in layer $40-50 \mathrm{~cm}$, presenting a variation in FA, $\mathrm{HA}$ and HUM respectively of 2.28 to $0.67 \mathrm{~g} \mathrm{~kg}-1,3.20$ to $0.93 \mathrm{~g}$ kg-1 and 8.22 to $2.41 \mathrm{~g} \mathrm{~kg}-1$ (Figure 2). Araújo Filho et al. (2018) attributes the highest carbon concentration in soil humic fractions in the superficial layer to the death of thin roots mainly of herbaceous, vegetable biomass disposition in soil and the microbial activity that acts in stabilization of this soil organic matter.

The higher $\mathrm{C}$ proportion in the humic fraction is important for soil organic carbon, and this fraction is composed of organic residues with a high degree of decomposition generating greater molecular stability, indicating a longer soil $\mathrm{C}$ permanence, attributing greater capacity of the area in storing carbon (Petter et al., 2017).

The HUM presented the highest results over the other fractions in all vegetation coverings and HA over FA, with emphasis on the soil of Eucalyptus sp. area which presented the highest $\mathrm{C}$ concentrations in humic fractions between the evaluated areas up to a depth $30 \mathrm{~cm}$. Protection of humic C in aggregate fractions and physical-biochemical protection through recalcitrant $\mathrm{C}$ in aggregates is one of the main mechanisms for preserving $\mathrm{C}$ in altered soil (Zhang et al., 2019). This fraction has a strong resistance to microbial activity and is strongly associated with the soil mineral fraction, especially in oxidic soils (Stevenson, 1994).

In contrast, with native forest and pasture area provided the soil with a low $\mathrm{C}$ concentration in FA and HUM in topsoil. According to Petter et al. (2017) and Kukuls et al. (2019) the greater AF solubility in acidic and basic environments and the leaching process of this fraction favors a more homogeneous distribution of $\mathrm{C}$ in $\mathrm{AF}$ fraction between soil layers. These results were corroborated by (Gmach et al., 2018; Guimarães et al., 2013; Kunlanit et al., 2019) who reinforce the greater HA and HUM stability and a greater FA lability with lower $\mathrm{C}$ levels in this fraction.

According to Doane et al. (2003) reinforce this theory in their study where the soil carbon dynamics in different cultivation systems at the California University were evaluated, and found higher concentrations of carbon respectively in HUM, HA and FA.

Studies by Sato et al. (2019) evaluating the humic fractions in Cerrado, found the highest $C$ levels in HUM fraction $\left(7.10 \mathrm{~g} \mathrm{~kg}^{-1}\right)$ in native Cerrado, in the HA fraction $\left(4.7 \mathrm{~g} \mathrm{~kg}^{-1}\right)$ in a integrated crop-livestock system under no-tillage and in FA fraction $\left(3.87 \mathrm{~g} \mathrm{~kg}^{-1}\right)$ in a conventional crop, values that corroborate what was found in this study. According to Kukuls et al. (2019) sandy soils cause more dynamic changes in the properties of SOM and consequently in the humic fraction according to the change in land use.

The change in vegetation cover affects the dynamics of organic matter fractions (Ferreira et al., 2020). The evaluated areas showed significant differences in total carbon stocks in the humic fractions of soil (FA, HA and HUM) (Figure 3). Studies by Guimarães et al. (2013) showed an increase in the percentage of humic substances in the total soil carbon stock, attributing this phenomenon to its recalcitrance mainly in the humin fraction, adsorption by the mineral matrix of soil and its intra-aggregate occlusion.

Most of the C stored in the soil is associated with humic fractions (Stevenson, 1994). The HUM stored most of carbon contained in humic fraction (Figure 3C), in agriculture area the HUM represented $61.69 \%$ of total carbon fraction, followed by Eucalyptus sp. area $60.02 \%$, native forest $57.93 \%$ and pasture $55.59 \%$. According to Araújo Filho et al. (2018) this fact occurs mainly in high concentrations of carbon in the humic fractions, action of soil density and clay content, since the carbon stored in the humic fraction is more recalcitrant in soils making it easier to maintain this element in the soil.

Studies by Ferreira et al. (2020) studying the dynamics of soil aggregation and carbon fractions in a fragment of Atlantic Forest in Paraná concludes that the change in land use promotes $\mathrm{C}$ storage in the most stable fractions (HUM), according to the results found in this study. According to Gray et al. (2019) analyzing determinants of soil organic carbon fractions in Australia identified the largest stocks of soil carbon in the humic fraction, which corroborates this study. In addition, Gray says that the stocks of humic organic carbon are higher in humid areas, with a decrease in hot and dry areas.

After HUM, the HA represented the largest total carbono stocks in humic fraction, with the agriculture area having the lowest stocks in $\mathrm{HA}\left(12.40 \mathrm{Mg} \mathrm{ha}^{-1}\right)$ in contrast to the areas of Eucalyptus sp., pasture and native forest that respectively presented $\left(14.78 ; 14.41\right.$ and $14.39 \mathrm{Mg} \mathrm{ha}^{-1}$ ) as seen in Figure 3B. Lower stocks of humic substances in areas where there has been a change in land use, such as agriculture, is evidenced by Liu et al. (2020) who evaluating changes in soil carbon stocks in Central Asia, states that, when changing the soil, the carbon present in labile and humic fractions drastically reduces after the change, that, with the growth of vegetation cover, the carbon in these fractions increases significantly. 

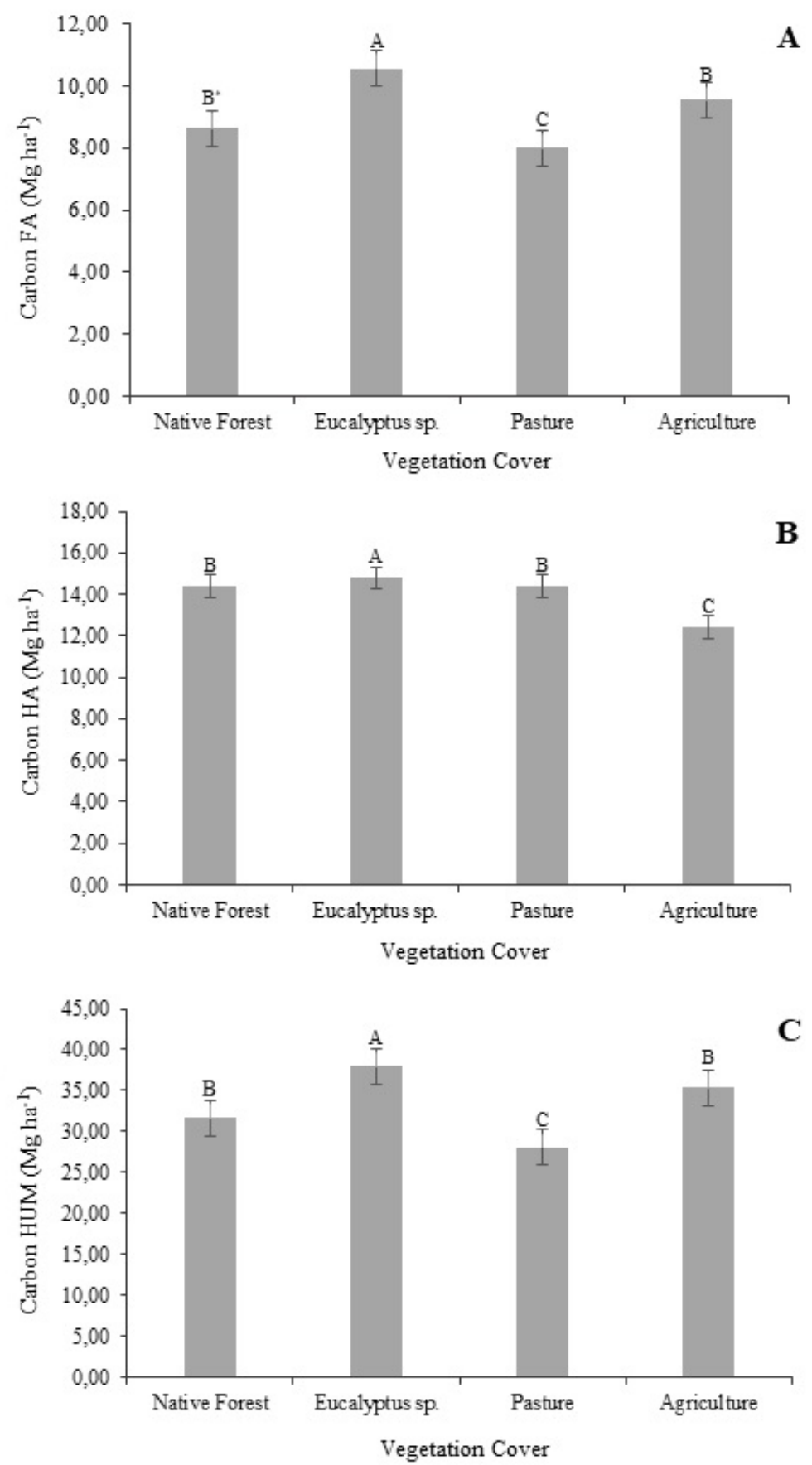

Figure 3. Total carbon stocks in humic fractions in different vegetation coverings in Gurupi-TO.

HA: Humic Acid; FA: Fulvic Acid; HUM: Humin.

"Significant differences are indicated by different letters by the Tukey test at $5 \%$ significance level $(\mathrm{P} \leq 0.05)$. Capital letters indicate differences between vegetation cover.

The Eucalyptus sp. area presented the largest carbon stocks in FA (10.55 $\left.\mathrm{Mg} \mathrm{ha}^{-1}\right)$, followed by agriculture, native forest and pasture areas that respectively presented (9.54; 8.62 and $7.99 \mathrm{Mg} \mathrm{ha}^{-1}$ ) (Figure 3A). According to Guimarães et al. (2013) evaluating the soil organic matter and carbon fractions in soil under different land uses concluded that chemical fractions of SOM is effective in evaluating changes in $\mathrm{C}$ dynamics, indicating that stocks present in humic fractions (FA, HA and HUM) are indicative of nature conservation. 


\section{CONCLUSIONS}

- $\quad$ Area with vegetation cover of Eucalyptus sp. presented higher carbon content in humic acid fraction, with a tendency to be more humid;

- Carbon of humic fractions was found in decreasing order: humin, humic acid and fulvic acid;

- $\quad$ Over time, the vegetable coverings of Eucalyptus sp. have the capacity to store $\mathrm{C}$ in more stable fractions of organic matter;

- In general, the pasture area showed lower concentrations and carbon stocks in fulvic acid and humine compared to the reference area, attributed to care lack and área abandonment.

- Agriculture area under conventional corn cultivation showed the potential to recover soil carbon stocks in fulvic acid and humine fractions, showing lower carbon reductions with increasing depth compared to other evaluated areas.

- Humic fractions of soil: humic acid, fulvic acid and humin are effective in assessing changes in the dynamics of $\mathrm{C}$ of the SOM in forest ecosystems.

\section{SUBMISSION STATUS}

Received: 17 Apr. 2020

Accepted: 26 Nov. 2020

Associate editor: João Vicente Latorraca (iD

\section{CORRESPONDENCE TO \\ Renisson Neponuceno Araújo Filho}

Universidade Federal do Tocantins, Rua Badejós, Chácaras 69 e 72, Lt. 07, CEP 77402-970, Gurupi, TO, Brasil

e-mail: nepoaraujo@gmail.com

\section{REFERENCES}

Almeida BG, Viana JHM, Teixeira WG, Donagemma GK. Densidade do solo. In: Teixeira PC et al. editores técnicos. Manual de métodos de análise de solo. 3 ed. Brasília: Embrapa; 2017.

Araújo Filho RN, Freire MBGS, Wilcox BP, West JB, Freire FJ, Marques FA. Recovery of carbon stocks in deforested caatinga dry forest soils requires at least 60 years. Forest Ecology and Management 2018; 407: 210-220.

Araújo Filho RN, Holanda FSR, Pedrotti A, Santos TO, Lino JB, Rocha IP, Influência dos atributos físico-mecânicos do solo na estabilidade do talude do rio São Francisco. Revista Scientia Agraria 2017; 18 (4): 107-113.

Bendito BPC, Souza PA, Ferreira RQS, Cândido JB, Souza PB. Espécies do Cerrado com potencial para recuperação de áreas degradadas, Gurupi (TO). Revista Agrogeoambiental 2018; 10 (2).
Dhaliwal SS, Naresh RK, Mandal A, Singh R, Dhaliwal MK. Dynamics and transformations of micronutrients in agricultural soils as influenced by organic matter build-up: A review. Environmental and Sustainability Indicators 2019; 1-2: 100007.

Doane TA, Deve^vre OC, Horwa'Th WR. Short-term soil carbon dynamics of humic fractions in low-input and organic cropping systems. Geoderma 2003; 114: 319-331.

Donagemma GK, Viana JHM, Almeida BG, Ruiz HA, Klein VA, Dechen SCF et al. Análise Granulométrica. In: Teixeira PC et al. editores técnicos. Manual de métodos de análise de solo. 3 ed. Brasília: Embrapa; 2017.

Ferreira CR, Silva Neto EC, Pereira MG, Guedes JN, Rosset JS, dos Anjos LHC. Dynamics of soil aggregation and organic carbon fractions over 23 years of no-till management. Soil and Tillage Research 2020; 198: 104533.

Ferreira DF. Sisvar: a computer statistical analysis system. Ciência e Agrotecnologia 2011;35 (6): 1039-1042.

Gmach MR, Dias BO, Silva CA, Nóbrega JCA, Lustosa-Filho JF, Siqueira-Neto M. Soil organic matter dynamics and land-use change on Oxisols in the Cerrado, Brazil. Geoderma Regional 2018; 14: e00178.

Gray J, Karunaratne S, Bishop T, Wilson B, Veeragathipillai M. Driving factors of soil organic carbon fractions over New South Wales, Australia. Geoderma 2019; 353: 213-226.

Guimarães DV, Gonzaga MIS, Silva TO, Silva TL, Dias NS, Matias MIS et al. Soil organic matter pools and carbon fractions in soil under different land uses. Soil and Tillage Research 2013; 126: 177-182.

Kukul̦ I, Kḷaviņš M, Nikodemus O, Kasparinskis R, Brūmelis G. Changes in soil organic matter and soil humic substances following the afforestation of former agricultural lands in the boreal-nemoral ecotone (Latvia). Geoderma Regional 2019; 16: e00213.

Kunlanit B, Butnan S, Vityakon P. Land-Use Changes Influencing C Sequestration and Quality in Topsoil and Subsoil. Agronomy 2019; 9: 520.

Liu X, Chen D, Yang T, Huang F, Fu S, Li L. Changes in soil labile and recalcitrant carbon pools after land-use change in a semi-arid agro-pastoral ecotone in Central Asia. Ecological Indicators 2020; 110: 105925.

Marinho Junior JL, Oliveira MD, Dias JLA, Araújo Filho RN, Melo Neto JO, Gonçalves SB et al. Physical Attributes of Soil in Different Forest Cover in South of Tocantins. International Journal of Plant and Soil Science 2019; 31 (2): 1-7.

Marinho PHA, de Sousa RM, Medeiros PCAO, Silva TGN, Giongo M. Levantamento fitossociológico de plantas infestantes na área experimental da Universidade Federal do Tocantins submetida a diferentes cultivos. Agrarian Academy 2017; 4 (7): 314-324.

Ondrasek G, Begić HB, Zovko M, Filipović L, Meriño-Gergichevich C, Savić R et al. Biogeochemistry of soil organic matter in agroecosystems and environmental implications. Science of The Total Environment 2019; 658: 1559-1573.

Pegoraro RF, Moreira CG, Dias DG, Silveira TC. Carbon and nitrogen stocks in the soil and humic substances of agricultural crops in the semi-arid region. Revista Ciencia Agronomica 2018; 49 (4): 574-583. 
Petter FA, Lima LB, Morais LA, Tavanti RFR, Nunes ME, Freddi OS et al. Carbon stocks in oxisols under agriculture and forest in the southern Amazon of Brazil. Geoderma Regional 2017; 11: 53-61.

Primieri S, Muniz AW, Lisboa HM. Dinâmica do Carbono no Solo em Ecossistemas Nativos e Plantações Florestais em Santa Catarina. Floresta e Ambiente 2017; 24: e00110314.

Santana MS, Sampaio EVSB, Giongo V, Menezes RSC, Jesus KN, Albuquerque ERGM et al. Carbon and nitrogen stocks of soils under different land uses in Pernambuco state, Brazil. Geoderma Regional 2019; 16: e00205.

Santos HG, Jacomine PKT, dos Anjos LHC, Oliveira VA, Lumbreras JF, Coelho MR et al. Sistema Brasileiro de Classificação de Solos. 5 ed. Brasília: Embrapa; 2018.

Sato JH, Figueiredo CC, Marchão RL, Oliveira AD, Vilela L, Delvico FM et al. Understanding the relations between soil organic matter fractions and $\mathrm{N}_{2} \mathrm{O}$ emissions in a long-term integrated crop-livestock system. European Journal of Soil Science 2019; 70 (6): 1183-1196.

Secretaria de Planejamento e Orçamento (SEPLAN). Gerência de Indicadores Econômicos e Sociais (GIES). Projeto de Desenvolvimento Regional Integrado e Sustentável. Zoneamento Ecológico-Econômico do Estado do Tocantins. Diagnóstico Ecológico-Econômico do Estado do Tocantins. Palmas: SEPLAN/ GIES; 2017.

Simon J, Costa RV, Almeida REM, Campos LJM, Lago BC, Ferreira LL et al. Época de plantio e cultivares de milho safrinha no Tocantins. Palmas, TO: Embrapa Pesca e Aquicultura, 2016. 18p.

Sisti CPJ, Santos HP, Kohhan R, Albes BJR, Urquiaga S, Bodey $\mathrm{RM}$. Change in carbon and nitrogen stocks in soil under 13 years of conventional or zero tillage in southern Brazil. Soil and Tillage Research 2004; 76: 39-58.

Soleimani A, Hosseini SM, Massah Bavani AR, Jafari M, Francaviglia $\mathrm{R}$. Influence of land use and land cover change on soil organic carbon and microbial activity in the forests of northern Iran. Catena 2019; 177: 227-237.

Souza ED, Silva CRM, Pinto FA, Carneiro MAC, Paulino HB, Pacheco LP et al. Soil quality indicators after conversion of "murundu" fields into no-tillage cropping in the Brazilian Cerrado. Pesquisa Agropecuária Brasileira 2019; 54: e00374.

Stevenson FJ. Humus chemistry: genesis, composition and reactions. 2nd ed. New York: Willey \& Sons; 1994.

Swift RS. Organic matter characterization. Methods of soil analysis. In: Sparks DL, Page AL, Helmke PA, Loeppert RH, Soltanpour PN, Tabatabai MA, Johnston CT, Sumner ME. (eds). Soil Science Society of America Book Series, 5. Part 3. Chemical Methods. Madison: Soil Science Society of America: American Society of Agronomy; 1996.

Vaz-de-Melo A, Taubinger M, Santos VM, Cardoso DP, Vale JC. Capacidade combinatória de milho para produção de grãos sob níveis de fósforo. Revista de Agricultura Neotropical2017; 4 (4): 15-25.

Veldkamp E. Organic carbon turnover in three tropical soils under pasture after deforestation. Soil Science Society of America Journal 1994; 58: 175-180.

Zhang J, Wei Y, Liu J, Yuan J, Liang Y, Ren J et al. Effects of maize straw and its biochar application on organic and humic carbon in water-stable aggregates of a Mollisol in Northeast China: A fiveyear field experiment. Soil and Tillage Research 2019; 190: 1-9. 